\title{
PREMENSTRUAL SYNDROME IN CHILDREN WITH TYPE 1 DIABETES MELLITUS
}

\author{
Yuliatul Machfudhoh ${ }^{1}$, Sri Yusnita Irda Sari², Novina Novina ${ }^{3}$ \\ ${ }^{1}$ Faculty of Medicine Universitas Padjadjaran, Bandung, Indonesia. \\ ${ }^{2}$ Departement of Public Health Faculty of Medicine Universitas Padjadjaran, Bandung, Indonesia. \\ ${ }^{3}$ Division of Endocrinology Department of Child Health, Faculty of Medicine, Universitas Padjadjaran / \\ Dr. Hasan Sadikin General Hospital, Bandung, Indonesia.
}

\begin{abstract}
Background: Premenstrual Syndrome (PMS) is a collection of symptoms that occur in women of reproductive age during the late luteal phase of the menstrual cycle. PMS is often experienced by women; studies say as many as $47.8 \%$ of women in the world experience PMS symptoms. Hormonal level and neurotransmitter may be expected to affect these symptoms. Type 1 Diabetes Mellitus (DM) can cause interference in metabolic control that can cause disruption of other hormone production that could affect the symptoms of PMS. Therefore, this study was conducted to observe PMS in children with type 1 DM.
\end{abstract}

Methods: This study was a cross-sectional descriptive study. Twenty-one children with Type 1 DM who followed up from August - November 2019 with the division of endocrinology, department of childhealth, Dr. Hasan Sadikin Bandung General Hospital were included in the study. Shortened Premenstrual Assessment Form (SPAF) questionnaire was used to observe the premenstrual syndrome.

Results: Fifteen (71.4\%) respondents experienced no to mild PMS symptoms and $6(28.6 \%)$ respondents experienced moderate to severe PMS symptoms. There was no significant correlation between the total score of PMS with HbA1c level ( $r=-0.174 ; p>0.05)$.

Conclusions: Most of the patients with type $1 \mathrm{DM}$ experience no to mild symptoms of PMS irrespective of HbA1c level.

\author{
ARTICLE HISTORY \\ Received 3 January 2020 \\ Accepted 28 May 2020
}

\section{KEYWORDS}

Premenstrual syndrome, Type 1 DM, HbA1C

\section{Introduction}

Premenstrual syndrome (PMS) is a collection of symptoms that occur in women of reproductive age during the late luteal phase of the menstrual cycle. ${ }^{1}$ According to The American College of Obstetricians and Gynecologists (ACOG), symptoms of PMS fall into two categories: 1) emotional and 2) physical symptoms. Emotional symptoms consist of depression, angry outbursts, crying spells, irritability, anxiety, confusion, social withdrawal, poor concentration, insomnia, increased naps taking, and changes in sexual desire; while physical symptoms consist of thirst and appetite changes, breast tenderness, bloating and weight gain, aches pain, fatigue, headaches, swelling of the feet and hands, skin problems, gastrointestinal symptoms, and abdominal pain. ${ }^{2}$ Symptoms of PMS can vary

CONTACT: Novina

Email: novina@unpad.ac.id

Address for Correspondence: Novina, dr., Sp.A (K), M.Kes Department of Child Health, Faculty of Medicine, Universitas Padjadjaran/ Dr. Hasan Sadikin General Hospital Jalan Pasteur No. 38, Bandung, 40161

(C)2020 Pediatric Oncall between individuals and can be influenced by many factors. The cause of PMS is still not known. However, several studies show that the hormonal factors and neurotransmitters play a role in the occurrence of PMS. ${ }^{1}$ PMS symptoms can be assessed using several tools. The tools for assessing PMS symptoms could be used with one-time or recurring measurement, depending on the tool used. Tools that use one-time measurement are Premenstrual Syndrome Screening Tools (PSST) and Shortened Premenstrual Assessment Form (SPAF), while tools that use recurring measurement are Premenstrual Symptom Diary (PMSD), Daily Record of Severity of Problems (DRSP), and Premenstrual Daily Symptom Diary (PDSD). ${ }^{3}$ In this study, PMS symptoms were assessed using a one-time measurement SPAF tool.

Research in 2013 states that as many as $47.8 \%$ of women in the world experience PMS. ${ }^{4}$ In Indonesia, a research conducted at Vocational High School Yogyakarta Indonesia stated that as many as $70.7 \%$ of the grade XI students experience PMS. ${ }^{5}$ In a study conducted on 85 female students of the Faculty of Social and Political Sciences at Airlangga University stated that as much as $78.7 \%$ of respondents experienced mild PMS symptoms and as many as $17.2 \%$ of respondents 
experienced severe PMS symptoms. The majority of respondents at the Faculty of Social and Political Sciences experienced mild physical and psychological symptoms. ${ }^{6}$

PMS has a significant impact on a person's quality of life. Patients who experience PMS reported that the symptoms affect their daily activities. Research conducted in Korean women found that as many as $14.3 \%$ of respondents with PMS experience problems with their daily activities on a moderate basis. ${ }^{7}$ A research done on reproductive age group in Europe and Latin America also showed that 35\% of the group had moderate to severe disruption in their daily activities due to PMS symptoms. ${ }^{8}$ Menstruation disorders are also often reported in people with Type $1 \mathrm{DM}$. Menstrual disorder that is often experienced by people with DM is irregular menstrual cycle. Irregularity of the menstrual cycle in patients with Type $1 \mathrm{DM}$ is thought to be related to changes in steroid sex hormone due to the disruption of insulin production. ${ }^{9}$

Research conducted on patients with Type 1 DM shows glucose levels in the menstrual cycle could vary. Glucose levels increased more in the menstrual luteal phase than in the follicular phase. This difference in glucose levels may be due to the effects of hormones. It has been found that the duration of menstrual cycle in patients with Type 1 DM is significantly longer than the control group and found an association between the menstrual cycle duration and HbA1C level. ${ }^{9-11}$

We undertook this study to observe PMS symptoms in children with Type 1 DM.

\section{Methods}

This was a cross-sectional descriptive study conducted from August - November 2019. Data were collected from 21 female patients aged $11-18$ years old who experienced menstruation and who had been diagnosed with Type 1 DM at Dr. Hasan Sadikin Bandung General Hospital with consecutive sampling method. Exclusion criteria were patients who do not have glycosylated hemoglobin ( $\mathrm{HbA} 1 \mathrm{c}$ ) level data, patients who experienced a malignancy in the reproductive organs, and patients who used the contraceptive pill. According to the American Diabetes Association (ADA), the optimal target of $\mathrm{HbA} 1 \mathrm{C}$ in diabetics was considered to be $<7.5 \%$, intermediate at $7.6 \%-8.9 \%$, and insufficient $>9.0 \% .{ }^{12}$ Data was collected by interviewing directly the patients with Type $1 \mathrm{DM}$ who signed the inform consent form. Before data collection, this study was approved by the Health Research Ethics Committee of Padjadjaran University with No. 751/ UN6.KEP/EC/2019.

PMS was assessed using the SPAF questionnaire. The SPAF questionnaire used is a questionnaire adapted from the PAF (Premenstrual Assessment Form). PAF is a diagnostic instrument of PMS which is composed of 95 questions about PMS symptoms. The SPAF is composed of 3 symptom subscales which are summarized in 10 questions. ${ }^{13}$ The SPAF score is divided into 2 categorises: No to mild PMS symptoms (score <30) and Moderate to severe PMS symptoms (score $\geq 30$ ). This questionnaire from World Health Organization (WHO) in english language, after translation to Indonesian was tested for validity and reliability using IBM SPSS ${ }^{\circledR} 20$. with the significance value $<0.05$ and cronbach's alpha 0.778 . Statistical analysis was carried out in Microsoft Excel and IBM SPSS ${ }^{\circledR}$ version 20 . The correlation test and descriptive statistics were calculated for all variables including mean and standard deviation. PMS with $\mathrm{HbA} 1 \mathrm{c}$ level correlation coefficient wass calculated using the Pearson correlation test.

\section{Results}

Table 1 shows the characteristics of the 21 patients with type 1 DM. The mean age at first diagnosis of Type 1 DM was $10.4 \pm 0.58$ years with age range of 4-15 years. Most subjects (76.2\%) experienced menarche after being diagnosed with Type 1 DM while the rest $(23.8 \%)$ experienced menarche after being diagnosed with Type 1 DM. The person-map-item (Figure 1) showed the distribution of questions with numbers 1-10. The higher the question, it is more easily answered by respondents. Based on personmap-items, it was found that, among the questions included in the questionnaire, the question most easily answered by respondents is question number 9 about the presence of edema, swelling, puffiness, or water retention related to PMS.

Table 1. Characteristic of respondents

\begin{tabular}{|c|c|}
\hline Characteristics & $\begin{array}{c}\text { Number of } \\
\text { patients } \\
(n=21)\end{array}$ \\
\hline \multicolumn{2}{|l|}{ Age (Years) } \\
\hline$($ mean $\pm S D)$ & $14.8 \pm 1.6$ \\
\hline $11-13$ years age group & $5(23.8 \%)$ \\
\hline $14-16$ years age group & $15(71.4 \%)$ \\
\hline $17-18$ years age group & $1(4.8 \%)$ \\
\hline $\begin{array}{l}\text { Menarche age } \\
\text { (Years) }(\text { mean } \pm \text { SD) }\end{array}$ & $12 \pm 0.89$ \\
\hline $\begin{array}{l}\text { Menstrual cycle length } \\
\text { (days) (mean } \pm S D)\end{array}$ & $28.1 \pm 3.2$ \\
\hline $\begin{array}{l}\text { Duration of menstruation } \\
\text { (days) (mean } \pm S D)\end{array}$ & $6.0 \pm 1.3$ \\
\hline \multicolumn{2}{|l|}{$\begin{array}{l}\text { Regularity of } \\
\text { menstruation }\end{array}$} \\
\hline Yes & $20(95.2 \%)$ \\
\hline \multicolumn{2}{|l|}{ Level of Education } \\
\hline Elementary School & $1(4.8 \%)$ \\
\hline Junior High School & $9(42.9 \%)$ \\
\hline Senior High School & $11(52.3 \%)$ \\
\hline \multicolumn{2}{|l|}{ PMS score } \\
\hline No symptoms to mild $(<30)$ & $15(71.4 \%)$ \\
\hline Moderate to severe $(\geq 30)$ & $6(28.6 \%)$ \\
\hline HbA1c $(\%)($ mean \pm SD) & $10.89 \pm 2.29$ \\
\hline HbA1c $<7.5 \%$ & $2(9.5 \%)$ \\
\hline HbA1c $7.6-8.9 \%$ & $2(9.5 \%)$ \\
\hline HbA1c >9.0 \% & $17(81 \%)$ \\
\hline
\end{tabular}


Figure 1. Person - Map - Item

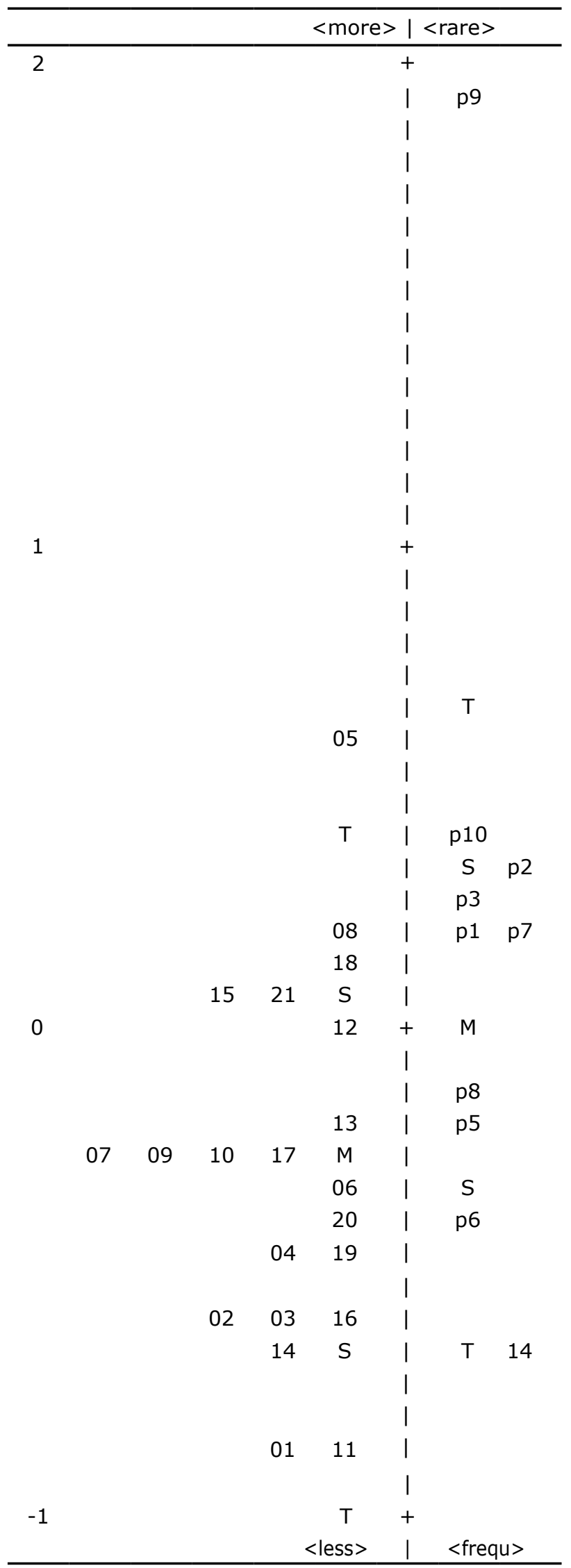

Table 2 shows SPAF score in each symptom of PMS. Each symptoms has scale from 1 (not present or no change from usual) to 6 (extreme change, perhaps noticeable even to casual acquaintances). In higher scale, 5 respondents $(23.8 \%)$ complained outburst of irritability or bad temper. While in lower scale, all of respondents $(100 \%)$ did not report any edema, swelling, puffiness, or water retention.

Table 2. Scale of Premenstrual syndrome symptoms in Shortened Premenstrual Assessment Form (SPAF)

\begin{tabular}{|c|c|c|c|c|c|c|}
\hline \multirow[t]{2}{*}{$\begin{array}{l}\text { Items of } \\
\text { SPAF }\end{array}$} & \multicolumn{6}{|c|}{$\begin{array}{c}\text { SPAF Scale } \\
n=21\end{array}$} \\
\hline & $\begin{array}{c}1 \\
\text { not } \\
\text { pres- } \\
\text { ent }\end{array}$ & 2 & 3 & 4 & 5 & $\begin{array}{c}6 \\
\text { extreme } \\
\text { change }\end{array}$ \\
\hline $\begin{array}{l}\text { Pain, } \\
\text { tenderness, } \\
\text { enlargement } \\
\text { or swelling of } \\
\text { breasts }\end{array}$ & 9 & 1 & 4 & 6 & 0 & 1 \\
\hline $\begin{array}{l}\text { Feeling } \\
\text { unable to } \\
\text { cope or over- } \\
\text { whelmed } \\
\text { by ordinary } \\
\text { demands }\end{array}$ & 9 & 6 & 2 & 1 & 1 & 2 \\
\hline $\begin{array}{l}\text { Feeling } \\
\text { under stress }\end{array}$ & 9 & 2 & 6 & 1 & 2 & 1 \\
\hline $\begin{array}{l}\text { Outburst of } \\
\text { irritability or } \\
\text { bad temper }\end{array}$ & 0 & 2 & 3 & 6 & 5 & 5 \\
\hline $\begin{array}{l}\text { Feeling sad } \\
\text { or blue }\end{array}$ & 5 & 3 & 2 & 5 & 3 & 3 \\
\hline $\begin{array}{l}\text { Backaches, } \\
\text { joint and } \\
\text { muscle pain, } \\
\text { or joint } \\
\text { stiffness }\end{array}$ & 3 & 2 & 4 & 3 & 6 & 3 \\
\hline Weight gain & 8 & 4 & 4 & 1 & 2 & 2 \\
\hline $\begin{array}{l}\text { Relatively } \\
\text { steady } \\
\text { abdominal } \\
\text { heaviness, } \\
\text { discomfort or } \\
\text { pain }\end{array}$ & 4 & 4 & 4 & 3 & 3 & 3 \\
\hline $\begin{array}{l}\text { Edema, } \\
\text { swelling, } \\
\text { puffiness, } \\
\text { or water } \\
\text { retention }\end{array}$ & 21 & 0 & 0 & 0 & 0 & 0 \\
\hline $\begin{array}{l}\text { Feeling } \\
\text { bloated }\end{array}$ & 12 & 1 & 3 & 1 & 4 & 0 \\
\hline
\end{tabular}


Table 3. Premenstrual syndrome based on their HbA1C Level

\begin{tabular}{|c|c|c|}
\hline \multirow{2}{*}{$\begin{array}{l}\text { Category } \\
\text { of glycemic } \\
\text { control based } \\
\text { on HbA1C level }\end{array}$} & \multicolumn{2}{|c|}{ Premenstrual Syndrome category } \\
\hline & $\begin{array}{l}\text { No to Mild } \\
\text { N (\%) }\end{array}$ & $\begin{array}{c}\text { Moderate to } \\
\text { severe } \\
\mathrm{N}(\%)\end{array}$ \\
\hline $\begin{array}{l}\text { Optimal } \\
(<7.5 \%)\end{array}$ & 0 & $2(9.5)$ \\
\hline $\begin{array}{l}\text { Intermediate } \\
(7.5-8.9 \%)\end{array}$ & $2(9.5)$ & 0 \\
\hline $\begin{array}{l}\text { Insufficient } \\
(>9.0 \%)\end{array}$ & $13(61.9)$ & $4(19.0)$ \\
\hline
\end{tabular}

Table 3 show the category of PMS based on HbA1C level. There was no correlation of total score of PMS with $\mathrm{HbA} 1 \mathrm{c}$ level $(r=-0.174 ; p>0.05)$.

\section{Discussion}

In our study, the average age of diagnosis of type $1 \mathrm{DM}$ was 10.4 years. This is in line with previous research findings which show that the average age of diagnosis for type $1 \mathrm{DM}$ is around the age of 10 years old. ${ }^{12}$ In our study, $28.6 \%$ had moderate to severe PMS which is similar to a study on Jordanian women where moderateto-severe PMS was $29 \% .^{14}$

Patients with insufficient glycemic control have a decrease in the formation of steroid hormones (steroidogenesis) reducing the level of hormones produced by the gonads, a situation called hypogonadism. This hypogonadism will also cause menstrual delays and other menstrual disorders. ${ }^{15,16}$ In our study, it was not found that optimal glycemic control tend to have milder symptoms of PMS suggesting that PMS is not affected by sex steroid hormones. ${ }^{17}$ In addition, there was no significant correlation between total score of PMS and HbA1C level. PMS can be caused by many factors, both from hormonal, neurotransmitter, body mass index, and stress level. ${ }^{1,5,18}$ In this study, other factors that might influence PMS symptoms were not assessed.

Based on person-map-items, it was found that, among the questions included in the questionnaire, the question most easily answered by respondents is question number 9 about the presence of edema, swelling, puffiness, or water retention related to PMS. This is evident from the results of the question that all respondents $(100 \%)$ answered with a score of 1 , indicating that all respondents confidently did not report the symptoms. This is not consistent with research conducted by Tacani PM et al which states $65 \%$ of Brazilian women between 20-40 years old experienced edema. These different results explain that the severity and incidence of PMS increases at the age of 20 years old and above while respondents in this study are below that age. ${ }^{19}$

The PMS symptoms with the highest score of prevalence and severity was about the outburst of irritability or bad temper. Study by Raval C et al. state that outburst of irritability is the most frequently reported symptoms among college students in India. ${ }^{20}$ Study among students in Ethiopia also state that most frequently reported symptoms of PMS is irritability. ${ }^{21}$ Other study showed that $54.0 \%$ of 618 assessed Japanese high school students experienced outburst of irritability and bad temper complaints. ${ }^{22}$ In conclusion, most of the patients with type 1 Diabetes Mellitus (DM) are categorized into having no to mild PMS. In our study, $23.8 \%$ complained outburst of irritability or bad temper with extreme changes from usual. All of the respondents $(100 \%)$ did not report any edema, swelling, puffiness, or water retention. Moderate to severe PMS was found only in $28.7 \%$ of the patients. There no correlation between total score of PMS and $\mathrm{HbA} 1 \mathrm{C}$ level.

Limitation of this study, was absence of control group from non-diabetic population. Other limitation is that SPAF questionnaire requires patients to recall the symptoms of premenstrual syndrome experienced one month ago. Another limitation of this study is the lack of assessment of an underlying personality/stress level, which could distort the perception and the reporting of PMS symptoms.

\section{Compliance with Ethical Standards \\ Funding: None \\ Conflict of Interest: None}

\section{References:}

1. Bulun SE. Physiology and Pathology of the Female Reproductive Axis. In: Kronenberg HM, Larsen PR, Melmed S, Polonsky KS, ed. Williams Texbook of Endocrinology. 13th ed. Elsevier; 2016:590-663.

2. American College of Obstetricians and Gynaecologists. Premenstrual Syndrome (PMS). Available at URL: https:// www.acog.org/patient-resources/faqs/gynecologicproblems/premenstrual-syndrome. Accessed on 15th April 2020

3. Lustyk MK, Gerrish WG, Shaver S, Keys SL. Cognitivebehavioral therapy for premenstrual syndrome and premenstrual dysphoric disorder: a systematic review. Arch Womens Ment Health. 2009;12(2):85-96.

4. Direkvand-moghadam A, Sayehmiri K. Epidemiology of Premenstrual Syndrome, A Systematic Review and MetaAnalysis Study. J Clin Diagn Res. 2014; 8(2): 106-109.

5. Pratiwi AM, Pratiwi EN, Utami DK, Lestari PP. Association of premenstrual syndrome to stress incident among XI grades in Yogykarta. Proceedings of the International Conference on Applied Science and Health (ICASH) 2017. Available at URL: http://garuda.ristekbrin.go.id/documents/ detail/826285. Accessed on 17th May 2020

6. Fatul S. Hubungan Premenstrual Syndrome dengan Tingkat Aktivitas Fisik Pada Mahasiswi Fakultas Ilmu Sosial dan Ilmu Politik Universitas Airlangga. AntroUnairdotNet. 2017;6:234-244

7. Choi D, Lee DY, Lehert $\mathrm{P}$, Lee IS, Kim SH, Dennerstein L. The impact of premenstrual symptoms on activities of daily life in Korean women. J Psychosom Obstet Gynaecol. 2010;31(1):10-15.

8. Dennerstein $L$, Lehert $P$, Bäckström TC, Heinemann $K$. The effect of premenstrual symptoms on activities of daily life. Fertil Steril. 2010;94(3):1059-1064.

9. Schweiger BM, Snell-Bergeon JK, Roman R, McFann $\mathrm{K}$, Klingensmith $\mathrm{G}$. Menarche delay and menstrual irregularities persist in adolescents with type 1 diabetes. 
Reprod Biol Endocrinol. 2011;9:61.

10. Barata DS, Adan LF, Netto EM, Ramalho AC. The effect of the menstrual cycle on glucose control in women with type 1 diabetes evaluated using a continuous glucose monitoring system. Diabetes Care. 2013;36(5):e70.

11. Gaete X, Vivanco M, Eyzaguirre FC, et al. Menstrual cycle irregularities and their relationship with $\mathrm{HbA} 1 \mathrm{c}$ and insulin dose in adolescents with type 1 diabetes mellitus. Fertil Steril. 2010;94(5):1822-1826.

12. American Diabetes Association. 13. Children and Adolescents: Standards of Medical Care in Diabetes-2019. Diabetes Care. 2019;42(Suppl 1):S148-S164.

13. Allen SS, McBride CM, Pirie PL. The shortened premenstrual assessment form. J Reprod Med. 1991;36(11):769-772.

14. Albsoul-Younes A, Alefishat E, Farha RA, Tashman L, Hijjih E, AlKhatib R. Premenstrual syndrome and premenstrual dysphoric disorders among Jordanian women. Perspect Psychiatr Care. 2018;54(3):348-353.

15. Nandi A, Poretsky L. Diabetes and the female reproductive system. Endocrinol Metab Clin North Am. 2013;42(4):915946.

16. Yeung EH, Zhang $\mathrm{C}$, Mumford SL, et al. Longitudinal study of insulin resistance and sex hormones over the menstrual cycle: the BioCycle Study. J Clin Endocrinol
Metab. 2010;95(12):5435-5442.

17. Wu M, Liang Y, Wang Q, Zhao Y, Zhou R. Emotion Dysregulation of Women with Premenstrual Syndrome. Sci Rep. 2016;6:38501.

18. Amiri Farahani L, Heidari T, Narenji F, Asghari Jafarabadi M, Shirazi V. Relationship between Pre Menstrual Syndrome with Body Mass Index among University Students. Hayat. $2012 ; 17$ (4) :85-95

19. Tacani PM, Ribeiro Dde O, Barros Guimarães BE, Machado AF, Tacani RE. Characterization of symptoms and edema distribution in premenstrual syndrome. Int J Womens Health. 2015;7:297-303. d

20. Raval CM, Panchal BN, Tiwari DS, Vala AU, Bhatt RB. Prevalence of premenstrual syndrome and premenstrual dysphoric disorder among college students of Bhavnagar, Gujarat. Indian J Psychiatry. 2016;58(2):164-170.

21. Abeje A, Berhanu Z. Premenstrual syndrome and factors associated with it among secondary and preparatory school students in Debremarkos town, North-west Ethiopia, 2016. BMC Res Notes. 2019;12(1):535.

22. Takeda T, Imoto $Y$, Nagasawa $H$, Muroya M, Shiina $M$. Premenstrual Syndrome and Premenstrual Dysphoric Disorder in Japanese Collegiate Athletes. J Pediatr Adolesc Gynecol. 2015;28(4):215-218. 